\title{
|Projekt „Literatura”
}

\section{„Literature" Project}

\author{
|Urszula Kowalska
Uniwersytet im. Adama Mickiewicza w Poznaniu
}

\begin{abstract}
The article presents opinions related to university literature teaching and the necessity (justified or not) of adapting teaching methods to the abilities of a modern recipient. It also concentrates on the problem with defining new generation of students, through the prism of digital technology. However, the fundamental issue to consider, is the problem of academic literary education, which often does not raise enthusiasm among students. Many of them are treating the subject as not practical enough. I also refer to my own teaching experience; expressing the point of view that literature defends itself, besides lacking strict rules of modern education and the need to diversify students discussions using innovative, activating methods. Its interpretation is, however, dependent on contemporary context. The article, notes the common change in reading, education and historical memory, presents the necessity of preserving traditional educational paths focused on dialogue and discussion about the reader's experience.
\end{abstract}

Key words: digital native, digital immigrant, edutainment, literary education, modern teaching methods, homo practicus.

Streszczenie: Artykuł prezentuje refleksje związane z uniwersytecką dydaktyką literatury oraz koniecznością (uzasadnioną bądź nie) dostosowania metod kształcenia do możliwości współczesnego odbiorcy. Poruszone zostały w nim także kwestie dotyczącego definiowania nowego pokolenia studentów przez pryzmat cyfrowych technologii. Fundamentalne dla rozważań jest jednak zagadnienie akademickiej edukacji literackiej, która nierzadko nie wzbudza entuzjazmu wśród studentów, traktujących przedmiot jako mało praktyczny. W tekście odwołuję się do własnych doświadczeń dydaktycznych, wyrażając przekonanie, że odarta ze sztywnych reguł współczesnego kształcenia oraz uwolniona z konieczności urozmaicania dyskusji nowatorskimi metodami aktywizującymi studenta, literatura broni się sama, podlegając jednak w głównej mierze interpretacji przez pryzmat współczesności. Artykuł, zwracając uwagę na przemiany czytelnictwa, edukacji i historycznej pamięci, prezentuje stanowisko wyrażające potrzebę powrotu do klasycznych ścieżek edukacyjnych - dialogu i dyskusji o doświadczeniu czytelniczym.

Słowa kluczowe: digital native, digital immigrant, edutainment, edukacja literacka, współczesne metody kształcenia, homo practicus. 
To nie jest początek kolejnego lamentu nad upadkiem czytelnictwa w Polsce.

(Ryszard Koziołek)

Nauczanie literatury w szkole powinno być karane kryminałem.

(Marek Hłasko)

\section{Dobrze się uczy literaturą ${ }^{1}$ (?)}

Trudno nie zgodzić się ze stwierdzeniem, że czytanie literatury jest kolejnym z etapów zapewniającym kulturową ciągłość, której humanista jest „depozytariuszem i strażnikiem” (Kostkiewiczowa 2014, 26). Moje niedługie doświadczenie $\mathrm{w}$ dydaktyce akademickiej potwierdza, że na zajęciach ze studentami lepiej sprawdza się lektura, wychodząca co prawda z klasycznych tendencji do przeanalizowania okoliczności powstania utworu, odkrycia, czym był i jaką rolę odegrał w konkretnym momencie historycznym (tu zawiązuje się, oczywiście, cały szereg wątków społecznych, politycznych i filozoficznych), dążąca jednak do „umieszczenia” literatury we współczesnym kontekście, często uniwersalizująca fabułę, postawy bohaterów, powieściowe dylematy. To perspektywa podobna do tej, o której pisał Ryszard Koziołek, zastanawiając się nad przyszłością przeszłości literatury (Koziołek 2014, 295-303), wyrywającej się „z ostateczności czasu dokonanego" (Koziołek 2014, 298). To także perspektywa, która, jak się wydaje trochę na przekór utyskiwaniom na temat niskiego poziomu wiedzy ogólnej wśród studentów czy braku umiejętności łączenia faktów, pozwala literaturze spełnić, przynajmniej częściowo, „humanistyczną funkcję”. „Poznanie humanistyczne ma w sobie zawsze coś z samopoznania” - twierdził Gadamer, a komentująca jego rozważania w artykule pod niepokojącym tytułem $C z y$ świat potrzebuje humanistów? Teresa Kostkiewiczowa dodaje:

Ważna jest tu szkolna i akademicka edukacja polonistyczna i historyczna, w której refleksji o dziedzinie aksjologii, o wyborach wartości i sposobach ich wprowadzania w życie służyć mogą zarówno poznawane dzieła literackie różnych epok, jak i biografie osobowości historycznych, skłaniające do zajęcia stanowiska wobec ich decyzji życiowych i realizowanych celów. Istotne jest tu także przemyślenie problematyki wzorów osobowych, ich potrzeby w świadomym kształtowaniu człowieka i roli dla poczucia integralności i spójności konkretnego „ja” (Kostkiewiczowa 2014, s. 27).

Fundamentem lektury, a także zdobywanej wiedzy, pozostaje dziś doświadczenie. Trudno je jednak „odziedziczyć”. Lektura oderwana od pierwotnych kontekstów niekoniecznie zubaża literaturę - może warto uznać, że ją po prostu w pewien sposób uniwersalizuje. Nie istnieje chyba żadna recepta na literackie przeżycie intelektualne, choć w epoce mierzących

${ }^{1}$ Zdanie jest parafrazą tytułu książki Ryszarda Koziołka Dobrze się myśli literatura (Koziołek 2016). 
wszystko efektów kształcenia trudno oderwać myśli od dydaktycznych powinności i obowiązujących treści nauczania. Jak pogodzić je z nieskrepowaną niczym rozmową ze studentami na temat intymnego ${ }^{2}$, bądź co bądź, przeżycia literackiego? A przede wszystkim, jak dobrać lektury, by zapewnić na zajęciach twórczą rozmowę, której zalążkiem musi być przecież osobista fascynacja wykładowcy, gwarantująca drażniące, prowokacyjne pytania, dialog, dyskusję. Mam to szczęście, że w instytucie, w którym pracuję, nikt jeszcze nie ingeruje w listę lektur do poszczególnych zajęć, również tych literackich. Muszą one, rzecz jasna, odzwierciedlać pewne procesy i tendencje historyczno-literackie charakterystyczne dla omawianej epoki, nawiązywać do kanonu wybranej literatury narodowej, ale ich dobór pozostaje wciąż przywilejem prowadzącego zajęcia. Z niepokojem myślę o końcu tej dydaktycznej wolności, którą z pewnością już wkrótce będzie trzeba ujarzmić i „zatabelkować”. Jak pesymistycznie, ale nie bez powodu przewiduje Dorota Heck:

zbliżamy się do sytuacji, kiedy urzędnik i autor ramowych sylabusów, choćby był niższy stopniem naukowym, będzie miał większy wpływ na wykładane treści niż doświadczony, posiadający twórczy dorobek profesor (Heck 2014, 315).

Jak wam się czytało? - to pytanie trywialne, przeciętne, infantylne, nienaukowe. Często jednak zaczynam od niego zajęcia, co nierzadko budzi zakłopotanie wśród studentów (jego powód może być trojaki: nie przeczytali w ogóle, wiedzą, że nie wystarczy odpowiedzieć dobrze/źle albo uważają pytanie za trywialne, przeciętne, infantylne, nienaukowe).

Cieszą niebanalne reakcje. Nawet takie, kiedy utwór napisany w latach 70. przez jednego z czołowych czeskich dysydentów wzbudza skrajne emocje i kilka osób z grupy nie dokończyło jego lektury z powodów „emocjonalno-estetycznych" (chodzi o tekst Ludvíka Vaculíka Świnki morskie, pozornie opowiadający o sympatycznych, kudłatych stworzeniach, w rzeczywistości będący kafkowskim traktatem o ludzkiej egzystencji). Refleksje studentów na temat hodowli kawii domowej (jak każe polskie nazewnictwo od 2015 roku) i ich komentarze odnośnie partii powieści, dotyczących charakterystycznych dla gatunku zachowań, są swoistą przerwą w dydaktyce, szczególnie w moim odczuciu potrzebną w trakcie rozmowy o tak mrocznym tekście, powstałym w równie mrocznej epoce czechosłowackiej neostalinizacji przełomu lat 60. i 70.

Jedno z ciekawszych spotkań intelektualnych ze studentami zdarzyło mi się na zajęciach ze słuchaczami pierwszego roku po lekturze stosunkowo nowej, prowokacyjnej powieści Jáchyma Topola, która w Polsce ukazała się pod tytułem Warsztat diabła (2013), a traktuje, w ogromnym skrócie, o rewitalizacji obozu koncentracyjnego w Terezínie. Wizja Topola daleka

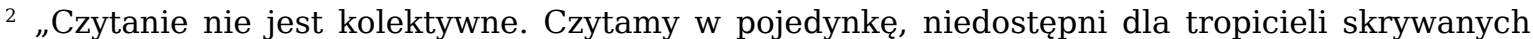
przyjemności. kiedy jednak inny czytelnik wyzna nam swoje przeżycie lektury, powstaje sugestia, że choć oddzieleni, uczestniczyliśmy we wspólnej intymnej przygodzie o wciąż zagadkowej treści" (Koziołek 2016, 15-16).
} 
jest od fikcji literackiej, co udowadniają chociażby mniej znane w Polsce, lepiej w Czechach, przykłady zjawiska zwanego dark tourism albo thanatourism. W języku polskim wciąż brakuje usankcjonowanego terminu, choć to właśnie zorganizowane wycieczki do obozu Auschwitz-Birkenau są podawane jako modelowy przykład „ciemnej turystyki”, szczególnej formy poznawania „interesujących” zakątków świata. Atrakcyjność przekazu historycznego to problem bardzo aktualny także we współczesnej Polsce, kiedy popularne stały się rekonstrukcje i inscenizacje historyczne (zwane także, co znamienne, festynami bądź widowiskami). Przewrotnie oczywiście realizują one dewizę, o której wspomina narrator Topola, powołując się na Jana Ámosa Komenskiego: postulat nauki przez zabawę. Terezínska komuna Topola, wytworzona jako alternatywa dla oficjalnej pamięci, reprezentowanej przez nieprawdziwy przestarzały, sztuczny Pomnik, zwraca uwagę na trudności, z jakimi borykają się twórcy podręczników, nauczyciele czy muzealnicy, stojący przed koniecznością (obiektywną bądź nie) dostosowania metod kształcenia do możliwości współczesnego odbiorcy, uwiarygodnienia i umocnienia świadectwa, które zostaje mu przekazane. Edyta Gietka w artykule zatytułowanym Głosy, który ukazał się w 2010 roku w „Polityce”, podsumowując uzależnione od narodowości typy wycieczek po dawnym obozie Auschwitz-Birkenau, tak scharakteryzowała „polski tryb zwiedzania" oraz przygotowujące do niego metody nauczania o Zagładzie:

Notatki. A jeśli jesteś licealistą z Polski, przed przyjazdem uczysz się pamiętania o Auschwitz z nowoczesnych podręczników za pomocą niestandardowych metod. Metody: mapa mentalna, metaplan, drzewo decyzyjne, metoda portfolio, tunel myśli. Hitem jest metoda: świadectwo audiowizualne, czyli wywiady z ocalonym. Czas trwania 3-5 min. Należy unikać fragmentów, gdzie ocalony reaguje w sposób skrajny, na przykład przywołane przeżycia wywołują u niego krzyk, głośny płacz lub inne (Gietka 2010).

Literacka wizja białoruskiego Muzejka (z wypchanymi ludźmi, jako eksponatami), naszkicowana przez czeskiego pisarza, jest ekstremalną reakcją na poczucie zagrożenia związanego z - makabrycznym w swoich skutkach poszukiwaniem najodpowiedniejszej formy zachowania historycznej i kulturowej pamięci. To także wynaturzony obraz lęku przed utratą pamięci, reprezentowaną przez świadków epoki.

Refleksja na temat dydaktyki literatury siłą rzeczy przeobraża się tu w refleksję na temat moralnych powinności stojących przed współczesną kulturą. Przywołana powyżej lektura skłoniła studentów do zaciętej dyskusji o ich własnych doświadczeniach - z dydaktyką szkolą, literaturą obrazującą Zagładę, wycieczkami do obozu koncentracyjnego czy wszechobecnymi rekonstrukcjami historycznymi. Półtorej godziny $\mathrm{z}$ tekstem Topola nie wymagało „powerpointowej” prezentacji, zdjęć, muzyki, pracy w grupach czy dramy. 
Dialog, spotkanie, elementy zaskoczenia, niespodzianki lub spontaniczności są przeciwieństwem „planów wykładów” z okresu stalinowskiego, które z goryczą wspominał znakomity matematyk, Hugo Steinhaus, a także sylabusów i ewaluacji, ingerujących w twórcze spotkanie osób na uniwersytecie (Heck 2014, 309).

Nie jest możliwe, by każdy tekst z listy lektur zaistniał w ten sposób, rzadko zdarza się zacięta dyskusja, w której wykładowca pełni jedynie funkcję moderatora. Ale do takich spotkań z literaturą i drugim człowiekiem warto chyba dążyć za wszelką cenę. Również za cenę multimedialnych prezentacji i audiowizualnych, aktywizujących(?) metod kształcenia.

Z obłędem w oczach szukam niekiedy po nocach filmu, utworu, strony internetowej czy chociaż obrazka, który urozmaici zajęcia. Ale jest tylko „wypełniaczem”. Nierzadko zabiera czas, który mógłby zostać przeznaczony po prostu na rozmowę.

Nasi studenci znajdą dużo lepsze obrazki, dotrą do dużo ciekawszych utworów, przygotują dużo bardziej profesjonalną prezentację. Moje wyszukane skrzętnie internetowe memy z Husem i dowcipy obrazkowe o tym, jak Słowacy postrzegają Czechów, w jakimś stopniu spełniają swoją funkcję. Sygnalizują: a) że Hus jest ważny, b) że relacje czesko-słowackie są skomplikowane. Może obraz połączony z komentarzem rzeczywiście lepiej zapadnie $\mathrm{w}$ pamięć ${ }^{3}$. Jednak studenci, mimo że dzieli nas stosunkowo niewielka różnica wieku, dużo lepiej poruszają się po obszarze tej współczesnej „ikonografii”. Dlaczego mam im udowadniać, że idę z duchem czasu, skoro zostałam wykształcona w innych sposób? Dlaczego mam marnować energię na mozolne przygotowywanie prezentacji, skoro mogłabym ją poświęcić na zaplanowanie rozmowy, przemyślenie scenariusza zajęć, sformułowanie pytań, które będą miały o co się zaczepić. Pewnie i tak zawisną w ciężkim milczeniu, znanym chyba każdemu wykładowcy. Ale może nie na długo?

Bombardujemy studentów obrazami - jak na ich podstawie mają nauczyć się mówić?

Bartosz Korzeniowski, pisząc o medialnych reprezentacjach pamięci historycznej, „która domaga się odpowiedzialności”, wspomniał także o komforcie uczestnictwa odbiorcy (Korzeniowski 2012, 17). Gdyby jego rozważania przenieść na płaszczyznę zajęć akademickich, można by stwierdzić, że film, slajd, obraz w pewnym sensie także zapewniają komfort uczestnictwa, nie zadają trudnych (lub pozornie trudnych) pytań. Największy problem jednak polega na tym, że ów komfort nie przygotuje uczestnika do sytuacji komunikacyjnej, jaką jest egzamin, obrona rozprawy dyplomowej lub... rozmowa o pracę.

Oczywiście, przedmioty nieliterackie rządzą się innymi prawami. Już teraz trudno mi sobie wyobrazić zajęcia z wiedzy o kraju i kulturze bez

\footnotetext{
${ }^{3}$ Nie bez powodu jednak studenci na egzaminie z czeskiej literatury mówią o tym, że Egon Bondy zginął wskutek pożaru od niedopałka, a Milena Jesenská miała romans z Franzem Kafką (tych informacji, jak łatwo się domyślić, nie było na żadnym slajdzie). Wiedza karmi się skandalem. Kuchenne schody szybciej prowadzą do świata literatury, bez względu na przynależność pokoleniową.
} 
wykorzystania sprzętu multimedialnego. Ale czy literatura tego potrzebuje? Moi studenci zareagowali śmiechem, kiedy zapowiedziałam im, że według nowych standardów nie mogę już stosować metody „kredy i tablicy”. Czy nie wmawiamy sobie, jak bardzo jest źle, jak nas ogranicza „obrazkowa młodzież”, „ekranowy czytelnik”, jak strasznie obniżył się poziom studentów? Pewnie to prawda, ale umieją więcej i lepiej w innych dziedzinach. Nie są „mocni” z tzw. wiedzy ogólnej, bo mają ją pod ręką, jest dostępna na ekranie telefonu w każdej chwili. Są za to świetni w wyszukiwaniu informacji, w „namierzaniu” źródeł (szczególnie tych w cyfrowych archiwach, umiejętnie korzystają z dobrodziejstw digitalizacji), umieją wskazywać zaskakujące konteksty, odnajdują we współczesności znaki historii, gry z konwencją, współczesne reinterpretacje klasycznych toposów. Starają się je zanalizować, ocenić, ale są świadomi tego, że brakuje im doświadczenia. Tak jak brakuje go mnie, choć od magicznej cezury roku $1990 \mathrm{w}$ dacie urodzenia, którą symbolicznie przyjmuje się jako pewien punkt graniczny różnych generacji, dzieli mnie kilka lat. A od współczesnych studentów odróżnia być może także osiem klas podstawówki, brak doświadczenia gimnazjum, inna formuła pisemnej matury z języka polskiego i pięcioletnie jednolite studia magisterskie. Wszyscy mamy inną pamięć, która determinuje lekturę. Trudno więc rozpocząć dialog. Również dlatego, że wynika on z ciekawości świata - zbyt łatwy dostęp do wiedzy („kliknij i masz”) być może tę ciekawość blokuje. Ale na pewno nie doszczętnie...

Idźmy tropem literatury, trzymając się jej - torowanej językiem - drogi przez doświadczenie siebie i świata. Weźmy wreszcie literaturę za przewodnika, a nie tylko za przedmiot naszych badań (Nycz 2012, 154).

\section{Perspektywa cyfrowego imigranta}

Odnoszę nieprzyjemne wrażenie, że studenci przestali być partnerami i stali się niepiśmiennymi troglodytami. Z coraz większym trudem przychodzi mi zainteresować ich tematem bez przeprowadzenia prezentacji powerpointowej, bez podsuwania im obrazkowych historii z myślenia, bez epatowania rzuconym na ekran cytatem. Nie łapią, że można obejść się bez tego. Nauka okazuje się dla nich za trudna lub nieinteresująca. Studenci są niedojrzali, dziecinni (Nowak 2012).

Ten fragment wypowiedzi potwierdza dość powszechne nastroje wynikające z obserwacji pokolenia dzisiejszych studentów. Profesor Piotr Nowak nie przebiera w słowach, nazywając podopiecznych również w mniej finezyjny sposób niż ten przywołany w cytacie. Ale czy naprawdę zasługują na taką krytykę?

W eseju zatytułowanym Digital Natives, Digital Immigrants z 2001 roku (być może ta data już go dezaktualizuje) Marc Prensky zwraca uwagę na edukacyjną współegzystencję przedstawicieli różnych generacji (nie w klasycznym ujęciu pokolenia jako grupy ludzi urodzonych w podobnym czasie, o przynależności generacyjnej świadczy tu raczej „doświadczenie 
technologiczne”) - cyfrowych „autochtonów” i imigrantów. Ci pierwsi bywają także określani jako przedstawiciele „pokolenia N” (net generation) lub „pokolenia D” (digital generation). Od urodzenia towarzyszą im współczesne technologie, Internet, powszechny dostęp do informacji, komputery, telefony komórkowe... Prensky, nawiązując do ich naturalnych zdolności, opisuje z kolei zmagania cyfrowych imigrantów, którymi są wszyscy, w mniejszym lub większym stopniu przystosowujący się do warunków cyfrowego świata. Potwierdzeniem, że także do nich należę, są wymienione przez autora artykułu przykładowe znaki szczególne tej grupy balansującej na granicy cyfrowego i „analogowego” świata: drukowanie maili, drukowanie tekstów w celu ich poprawienia, ciągnięcie ludzi do gabinetu, by pokazać im interesującą stronę internetową czy wreszcie dzwonienie w celu potwierdzenia, czy doszedł nasz e-mail (Prensky 2001, 1-2). Prensky wymienia także nowe umiejętności, konieczne do przetrwania w nowym świecie, sugerując niejako potrzebę adaptacji cyfrowych imigrantów. Trudno dyskutować z zaprezentowanymi w artykule wnioskami, wynikającymi z medycznych badań na temat zmodyfikowanych struktur mózgowych, trudno także nie zgodzić się z poniższym wnioskiem autora:

W odniesieniu do geografii - tak współcześnie ignorowanej - wydaje się niemożliwe, że pokolenie, które umie zapamiętać ponad 100 bohaterów Pokémon z ich opisami, informacjami na temat ich historii i rozwoju, nie jest w stanie nauczyć się nazw, liczby ludności czy stolic wszystkich 101 narodów świata. Różnica polega tylko na sposobie prezentacji (Prensky 2001, 5, tłum. U. Kowalska).

Czy rzeczywiście proces myślowy oraz mechanizm przetwarzania informacji charakterystyczny dla współczesnych studentów jest „fundamentalnie inny" (Prensky 2001, 1) niż dla tych, drukujących maile, technologicznie ułomnych przewodników po świecie literatury, kultury i języka? Mimo wszystko sądzę, że nie, choć oczywiście prezentacja (przede wszystkim ta werbalna) ma fundamentalne znaczenie.

Jako cyfrowy imigrant (coraz częściej mam wrażenie, że w moim pokoleniu chyba nie wypada nim być...) doceniam osiągnięcia współczesnych technologii w zakresie edukacji. Moje zainteresowania naukowe zmusiły mnie do zagrania $\mathrm{w}$ pierwszą bodaj w życiu poważną grę komputerową (nie licząc słynnego Tetris i popularnej niegdyś gry w samounicestwiające się robaki). Zdobywający uznanie na całym świecie multimedialny projekt Československo 38-89 (http://cs3889.cz/) jest grą edukacyjną opartą na źródłach pisanych oraz osobistym świadectwie, odwołującą się między innymi do czeskiego doświadczenia II wojny światowej. Pomysł, jak się wydaje, zupełnie nowy (przynajmniej w Czechach, bo tego rodzaju edukacyjna inicjatywa ma swoich prekursorów na świecie) jest kombinacją interaktywnej gry, podręcznika, komiksu a nawet, jak podkreśla twórca i koordynator Vít Šisler, wirtualnego muzeum. 
W rezultacie powstała „gra”, która nie mieści się tylko w sferze rozrywki, ale jest przedsięwzięciem interdyscyplinarnym, edukacyjno-artystycznym ${ }^{4}$.

Do znanego, początkowo entuzjastycznie, po latach różnie ocenianego zjawiska edutainmentu dochodzi obecnie nowe - tzw. infotainment, którego założenia, bardziej lub mniej świadomie, realizują współcześnie filmy, programy telewizyjne, gry planszowe czy komputerowe, strony internetowe i projekty multimedialne, media społecznościowe czy też szczególnie popularne w ostatnich latach tzw. rekonstrukcje i festiwale historyczne. Wspomniany już Vít Šisler zwrócił uwagę na fakt, że w nowoczesnym szkolnictwie na edutainment nie ma już miejsca, gdyż jest on przestarzałą formą „przykrywania” trudnych edukacyjnie treści zabawą, przy błędnym założeniu, że każda metoda uatrakcyjnienia przynosi dobre efekty - dla takiego uproszczonego dydaktycznego myślenia funkcjonuje już osobny termin: sugar-coated learning (Dobrovský 2014, 35). Bardzo istotnym elementem wymyślonej przez Šislera gry (zdaję sobie sprawę z tego, że to określenie odrobinę dezawuuje pomysł czeskich twórców, nie o prostą symulację tu bowiem chodzi, nie o kolejną „zabawę w przeżywanie”) jest sztuka prowadzenia rozmowy ze świadkami historii - gra podsuwa alternatywne pytania i reakcje, ich wybór zależy od gracza, wyznaczającego tym samym kierunek dialogu. Niewłaściwe pytanie (zbyt aroganckie, niedelikatne lub ignoranckie) może wywołać u interlokutora złość lub zniecierpliwienie, a tym samym zakończyć rozmowę i uniemożliwić przejście na kolejny poziom. Właśnie między innymi od analizy źródeł i doboru odpowiednich słów zależy, czy uda się użytkownikowi odkryć tajemnicę przeszłości dziadka i... wygrać.

\section{Homo practicus}

Współczesny odbiorca to podobno odbiorca, który nie czyta. Na studiach filologicznych akceptacja takiego założenia rodzi frustrację, często prowadzącą do kapitulacji - sama nierzadko proszę studentów, żeby chociaż dzielili się lekturami, by w kilkunastoosobowej grupie można było wciągnąć do dyskusji stricte literackiej 2-3 osoby. Dlaczego nie czytają (choć to, moim zdaniem, zbyt generalizujące pytanie)? Czy dlatego, że nie mają czasu? A może dlatego, że przedmioty literaturoznawcze wydają się coraz mniej ważne? Zaangażowanie na lektoracie (wiedza praktyczna, przydatna w sposób oczywisty) gwarantuje konkretną korzyść. Znużenie na literaturze być może wynika z braku dostatecznej argumentacji, do czego TA wiedza może się przydać (choć to mało krzepiące, że trzeba takie rzeczy tłumaczyć). Piszę to z pespektywy literaturoznawcy i promotora prac licencjackich, który ma szansę prowadzić także zajęcia z przedmiotów bardziej

\footnotetext{
${ }^{4}$ Warto zwrócić uwagę na ważny aspekt subiektywizacji wypowiedzi, odnoszenia się do różnych świadectw i rozmów z uczestnikiem wydarzeń. Ważna jest także narzucona przez twórców rola, w jaką wchodzi potencjalny odbiorca - poniekąd zostaje sobą, jego zadaniem nie jest na całe szczęście przeprowadzenie zamachu na Reinhardzie Heindrichu czy przetrwanie przesłuchaniu. Ma uzyskać informacje, zapoznać się z autentycznymi dokumentami, szukać wiadomości, by - zgodnie z fikcyjną fabułą gry - dowiedzieć się czegoś o swoim dziadku, który w 1942 roku został zabrany przez gestapo.
} 
„pragmatycznych” - pozwala to na pewien kontekst porównawczy, istotny w niewesołej refleksji nad miejscem modułów, nazwijmy je „literackich”, w edukacji akademickiej.

Kiedy otrzymałam zadanie poprowadzenia samych „praktycznych przedmiotów", poczułam żal, że nie będę mogła porozmawiać ze studentami o literaturze. A przecież prowadzenie zajęć z przekładu, wiedzy o kraju i kulturze oraz lektoratów po pierwsze ogranicza frustrację związaną z nieprzygotowaniem studentów („bo w bibliotece była tylko jedna książka, w dodatku za gruba"), po drugie gwarantuje frekwencję i zaangażowanie.

Tymczasem brakuje mi niekiedy sił i wiary na podkreślanie pragmatyzmu literatury. Udziela się zniechęcenie wywołane nadmiarem czytelniczych powinności („czasownik «czytać» nie znosi trybu rozkazującego” [Pennac 2007, 79]), niesłabnącym poczuciem „niedoczytania”. W takich momentach zwątpienia daję sobie wmówić, że nasi studenci potrzebują innego kształcenia, że mają rację, narzekając na zbyt dużo literackich przedmiotów. Że literatura nie daje im tak potrzebnej praktycznej wiedzy i umiejętności. Wiem, nic bardziej mylnego:

Powieści mówią nam, jak zupełnie niepodobni do nas ludzie myślą o sobie, w jaki sposób udaje im się przedstawić bulwersujące nas postępowanie w dobrym świetle, jak nadają swemu życiu sens. Problem, jak żyć własnym życiem, staje się wówczas problemem, jak rozważyć nasze potrzeby w kontekście ich potrzeb oraz ich samoopisy w kontekście naszych. Posiadanie bardziej wykształconego, bardziej rozwiniętego i bardziej wyrobionego poglądu moralnego oznacza zdolność do pojęcia większej ilości potrzeb i zrozumienia więcej samoopisów (Rorty 2006, 186, cyt. za: Szczukowski 2014, 412).

Jako wykładowcy akademiccy stajemy przed narastającym problemem braku umiejętności czytania, pisania i mówienia, a także rozpoznania i docenienia wartości własności intelektualnej. Trudno dociekać, czy trudności te wynikają ze zmiany systemu, edukacyjnej rewolucji, dydaktycznych zaniedbań, uspakajających diagnoz, że „to przecież nie nasza wina” czy - jak wolą niektórzy - ewolucyjnych procesów zachodzących w ludzkim mózgu. Wciąż za mało jest jednak badań, by mówić o casusie współczesnego człowieka - nie wiemy jeszcze, na ile współczesne media powodują spustoszenie czy rozwój. Bulwersuje i irytuje nas brak notatek, książek na ławkach, nieumiejętność „pracy z tekstem”, krótka pamięć czytelnika. Ale oczywisty pozostaje przecież związek przeżycia literackiego z egzystencjalnym, praktyczna strona literatury, polegająca na czerpaniu z dorobku poprzednich pokoleń.

Ludzie mogą nie czytać, tylko że są wtedy pozbawieni pewnej dyspozycji intelektualnej, której nie sposób nabyć inaczej (...) nieczytającym zanika pewien organ. (...) ten rodzaj organizowania świata za sprawą narracji i metafory, sensownego przedstawiania sobie zdarzeń i przeżyć, którego dokonujemy, czytając, jest niemożliwy do powtórzenia inaczej niż w języku (Koziołek 2016, 17). 
Konkursy grantowe na podniesienie kwalifikacji słuchaczy studiów humanistycznych wymagają od nas deprecjonowania kompetencji zawodowych naszych studentów - lament nad tym, jak trudna jest sytuacja humanisty na rynku pracy, chyba nie znajduje potwierdzenia w praktyce. Rynek pracy zdaje się dorastać do docenienia kogoś „z otwartym umysłem”, umiejącego formułować swoje myśli w mowie i piśmie.

Umiejętności humanistyczne, zwłaszcza zaś sztuka interpretacji literatury, mają charakter twórczy, niepowtarzalny, nie dają się zredukować do technik oderwanych od jednostkowej osobowości ludzkiej (Heck 2014, 311).

Dążenie do tego, by kierunki humanistyczne współpracowały z gospodarką, jest jak najbardziej rozsądne. Sama, właściwie przez przypadek, stałam się w zeszłym roku uczestnikiem projektu ministerialnego, w ramach którego młodzi naukowcy, reprezentujący różne dziedziny badawcze, wyjeżdżali do zagranicznych ośrodków na dwutygodniowe kursy z tak zwanych umiejętności miękkich i przedsiębiorczości. Nie widziałam tam dla siebie miejsca, szczególnie po długim i mozolnym procesie rekrutacyjnym, który składał się z wielu testów psychologicznych, autoprezentacji w języku angielskim i ponaddwugodzinnym trwaniu przed monitorem podczas gier Clustermind i Archipelago. Długo potem przeżywałam swoją wirtualną porażkę na stanowisku „opiekuna”, który miał dbać o kondycję psychiczną naukowców w swojej korporacji. Było mi przykro, gdyż naiwnie sądziłam, że jako filolog nie będę musiała w życiu zajmować się grami komputerowymi. Moja urażona duma pilnowała, żebym do końca negowała proces rekrutacyjny, nawet po zakwalifikowaniu się do programu. Zdegustowana faktem, że się do niego dostałam(!) i że będę musiała spędzić dwa tygodnie w jakimś szwedzkim miasteczku, ucząc się tego, co wszak doskonale wiem(!), z jeszcze większym sceptycyzmem zareagowałam na konieczność lektury książki pt. Business Model Generation (na całe szczęście miała dużo obrazków może i ja jestem ekranowym czytelnikiem). Nie zamierzam tu opisywać, jak bardzo moje lęki i frustracje ucierpiały w zderzeniu ze szwedzką rzeczywistością. Za istotny dla niniejszych rozważań uważam jednak fakt dużego entuzjazmu (ze strony prowadzących zajęcia oraz innych członków grupy) na wieść o tym, że jestem bohemistką. U Polaków entuzjazm ten ma zwykle podłoże żartobliwe, wynika ze stereotypowego myślenia o Czechach i języku czeskim. Ale tam, w grupie dwudziestu „ścisłowców” - informatyków, biologów, technologów żywności, medyków, ekonomistów - pojawienie się humanisty było zjawiskiem rzadkim i jednocześnie bardzo pożądanym, jakby wiedza na temat jego naturalnych predyspozycji pozwalała wierzyć, że jest predestynowany do zawodowego sukcesu. Skłaniam się więc ku koncepcji Tomasza Chachulskiego, który twierdzi:

szerokość humanistycznego horyzontu, kultura literacka i znajomość literatury, która jest jednym z najważniejszych mediów poznawania świata, rozumienie dowolnie zorganizowanego tekstu artystycznego (literackiego, innego tekstu kultury, 
w końcu każdego tekstu), daje im [humanistom - U.K.] przewagę nad wieloma innymi zawodami (...). W przeszłości wykształcenie humanistyczne było kluczem do obejmowania bardzo wielu wysokich stanowisk i dało stosowną formację intelektualną twórcom wielu innych nauk spoza tego obszaru (także ścisłych czy ekonomicznych). I być może problem nie leży po stronie pracowników naukowych i absolwentów polonistyki (także innych kierunków humanistycznych), uniwersytetów i innych szkół wyższych, lecz kryje się w braku stosownych kompetencji i świadomości urzędników państwowych i szefów firm (Chachulski 2014, 55-56).

W ostatnim czasie zajmuję się historią. Tą najbardziej bolesną, tragiczną. I jej wersją z przedrostkiem „pop”. Naukowo interesują mnie zadania współczesnej pamięci. Przyglądam się zjawiskom związanym z (nachalnym niekiedy) upamiętnianiem historycznych już dziś wydarzeń i doświadczeń, przy balansowaniu na cienkiej granicy decorum. Poczesne miejsce w tych rozważaniach zajmuje dyskusja o metodzie - utrwalania, przekazywania, edukowania. Nie jestem pamięciową terrorystką - wierzę, że komiks, film, gra, ekspozycja multimedialna także mogą „dawać świadectwo". Wydaje mi się, że przemiany towarzyszące powszechnym na całym świecie metodom przedstawiania (traumatycznej niekiedy) historii (m.in. w placówkach edukacyjnych), konieczność informatyzacji i medializacji pamięci, dotyczą wszystkich sfer kultury. Paradygmat pisma jest dziś zastępowany przez paradygmat obrazu, ikony - to z jednej strony zmiana rewolucyjna, $\mathrm{z}$ drugiej (być może niepokojący?) powrót do korzeni. Fragmentaryczność i epizodyczność charakteryzujące współczesne narracje historyczne dobrze pokazuje chociażby, niezwykle często dziś wykorzystywane do przekazania historycznych treści, medium komiksu czy animacji.

Ale nowatorskim zabiegom dokonywanym na pamięci historycznej towarzyszy też powrót do rozmowy, wysłuchania świadectwa. To prawdopodobnie niezbyt fortunne porównanie, jednak wydaje mi się, że skoro kultura w tym miejscu zatacza koło, to zacznie je zataczać także kultura edukacji. Prezentacje, filmy, dramy, case studies zaczynają nudzić. Być może powoli nadchodzi czas, kiedy studenci zasypywani różnymi rozrywkowo-edukacyjnymi hybrydami odetchną przy normalnej rozmowie? To nie pobożne życzenie czy przeczucie, wiem to od samych studentów, którzy chcą rozmawiać. O ile lektura ich porusza.

Faktem jest, że coraz trudniej ich (nimi?) poruszyć, ale znudzenie i zniecierpliwienie, wrażenie wtórności czy nawet pobłażanie to również emocje, z którymi można polemizować, które mogą stać się fundamentem ciekawej dyskusji. Nierzadko czuję zniecierpliwienie i narzekam, że podczas zajęć rozmawiałam sama ze sobą. Ale tydzień później kolejne spotkanie pokazuje, że może poprzednio źle postawiłam pytania. Albo nie czekałam wystarczająco długo na odpowiedź. Wiadomo wszak, jakim modyfikacjom podlega „trwanie”, kiedy w sali zapada cisza - ciągnąca się w nieskończoność, 
w rzeczywistości zaś utrzymująca się 10 sekund, po których każdy wreszcie chciałby przecież usłyszeć odpowiedź.

Literatura uczy pewnej samodzielności - w myśleniu, wartościowaniu, ocenie. Trudno oprzeć się wrażeniu, że pełni bardzo istotną funkcję w kształtowaniu tak pożądanych dziś na rynku pracy umiejętności miękkich. Oczywiście o dydaktycznym sukcesie decyduje wiele czynników - jednym z nich, być może najważniejszym, nad którym usilnie pracuję, jest przekonanie prowadzącego zajęcia, że jego przedmiot ma sens i zajmuje ważne miejsce we współczesnej edukacji oraz że naprawdę istnieje rodzaj kompromisu między, cytując Teresę Kostkiewiczową, „dyspozycjami «mieszkańca światów wirtualnych» a zdolnościami intelektualnymi «człowieka książkowego»" (Kostkiewiczowa 2014, 29).

Jestem winna wyjaśnienia dotyczące tytułu - liczę, że nie zostanie on potraktowany zupełnie poważnie. Moi studenci niezwykle często używają określenia „projekt”. Nic w tym dziwnego, współcześnie wszystko jest projektem. W epoce komercjalizacji wszystkiego, może uda się nie skomercjalizować literatury. A może właśnie trzeba z niej uczynić rodzaj przedsiębiorstwa? Promować (według sprawdzonych marketingowych wytycznych) klasyczną, literacką metodę samopoznania? Termin „projekt” funkcjonuje dziś trochę w oderwaniu od pierwotnego znaczenia, na które wskazują choćby synonimy: koncepcja, pomysł, zamysł, zamiar, intencja, inicjatywa, idea, propozycja, program, plan działania, szkic, zarys, schemat, wstępna wersja. To próba testowana na żywym organizmie, jakim jest grupa studentów. Wierzę jednak, że projekt „Literatura” można zrealizować przy użyciu sprawdzonych metod, niekoniecznie wpisujących się w korporacyjne standardy.

\section{Literatura}

Chachulski Tomasz, 2014, Polonistyczne wybory. Między klasycznym fundamentem a koniecznościa zmian, w: Biedrzycki K., Bobiński W., Janus-Sitarz A., Przybylska R. (red), Polonistyka dziś - kształcenie dla jutra, Kraków, s. 52-57.

Dobrovský Pavel, 2014, Hry se nedají od politiky oddělit. Rozhovor s Vítem Šislerem, „Level”, nr 248, s. 34-41.

Gietka Edyta, 2010, Głosy. Jak opowiedzieć Auschwitz, „Polityka”, http://www. polityka.pl/tygodnikpolityka/spoleczenstwo/1502591,1,jak-opowiedziecauschwitz.read (dostęp 15.09.2016).

Heck Dorota, 2014, Apologia i apoteoza, czyli spis lektur na studiach, w: Biedrzycki K., Bobiński W., Janus-Sitarz A., Przybylska R. (red), Polonistyka dziś - kształcenie dla jutra, Kraków, s. 308-319.

Korzeniowski Bartosz, 2012, Obrazy i klisze. Między biegunami wizualnej pamięci Zagłady, Kraków.

Kostkiewiczowa Teresa, 2014, Czy świat potrzebuje humanistów?, w: Biedrzycki K., Bobiński W., Janus-Sitarz A., Przybylska R. (red), Polonistyka dziś kształcenie dla jutra, Kraków, s. 25-31. 
Koziołek Ryszard, 2014, Komu opowiadać o przeszłości literatury polskiej, w: Biedrzycki K., Bobiński W., Janus-Sitarz A., Przybylska R. (red), Polonistyka dziś - kształcenie dla jutra, Kraków, s. 295-303.

Koziołek Ryszard, 2016, Dobrze się myśli literatura, Wołowiec.

Nowak Piotr, 2012, Hodowanie troglodytów, „Rzeczpospolita”, http://www.rp.pl/ artykul/905410-Hodowanie-troglodytow.html\#ap-1 (dostęp 15.09.2016).

Nycz Ryszard, 2012, Poetyka doświadczenia. Teoria - nowoczesność - literatura, Warszawa.

Pennac Daniel, 2007, Jak powieść, Bieńkowska K. (przeł.), Warszawa.

Prensky Marc, 2001, Digital Natives, Digital Immigrants, „On the Horizon”, nr 5, s. 1-6, http://www.nnstoy.org/download/technology/Digital+Natives++Digital+Immigrants.pdf (dostęp 15.09.2016).

Rorty Richard, 2006, Wybawienie od egotyzmu: James i Proust jako ćwiczenia duchowe, Żychliński A. (przeł.), „Teksty Drugie”, nr 1-2, s. 181-204.

Szczukowski Dariusz, 2014, Nauczanie literatury jako wyzwa(la)nie i wyznanie, w: Biedrzycki K., Bobiński W., Janus-Sitarz A., Przybylska R. (red), Polonistyka dziś - kształcenie dla jutra, Kraków, s. 409-419.

\section{O Autorce:}

Urszula Kowalska, absolwentka studiów bohemistyczno-polonistycznych, adiunkt Instytutu Filologii Słowiańskiej Uniwersytetu im. Adama Mickiewicza w Poznaniu. Autorka publikacji poświęconych m.in. czeskiej literaturze emigracyjnej oraz współczesnym przemianom pamięci historycznej w Europie Środkowej. W roku 2015 opublikowała książkę „Tato noc nebude krátká..." Doświadczenie roku 1968 w czeskiej literaturze emigracyjnej. Jej działalność dydaktyczna obejmuje zajęcia z zakresu wiedzy o kraju i kulturze Czech, teorii i praktyki przekładu, praktycznej nauki języka czeskiego oraz historii literatury czeskiej XX i XXI wieku. 
